\title{
WestVirginiaUniversity
}

THE RESEARCH REPOSITORY @ WVU

West Virginia Agricultural and Forestry Experiment

Davis College of Agriculture, Natural Resources

Station Bulletins

And Design

$1-1-1955$

\section{Some features of feed marketing in West Virginia}

Norman Nybroten

James M. Kesecker

Follow this and additional works at: https://researchrepository.wvu.edu/

wv_agricultural_and_forestry_experiment_station_bulletins

\section{Digital Commons Citation}

Nybroten, Norman and Kesecker, James M., "Some features of feed marketing in West Virginia" (1955). West Virginia Agricultural and Forestry Experiment Station Bulletins. 373.

https://researchrepository.wvu.edu/wv_agricultural_and_forestry_experiment_station_bulletins/367

This Bulletin is brought to you for free and open access by the Davis College of Agriculture, Natural Resources And Design at The Research Repository @ WVU. It has been accepted for inclusion in West Virginia Agricultural and Forestry Experiment Station Bulletins by an authorized administrator of

The Research Repository @ WVU. For more information, please contact ian.harmon@mail.wvu.edu. 


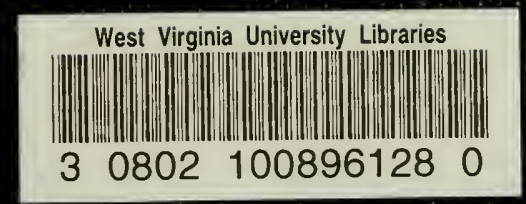

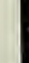


Digitized by the Internet Archive in 2010 with funding from

Lyrasis Members and Sloan Foundation 


\section{BULLETIN 373 \\ April 1955}

Some Features of
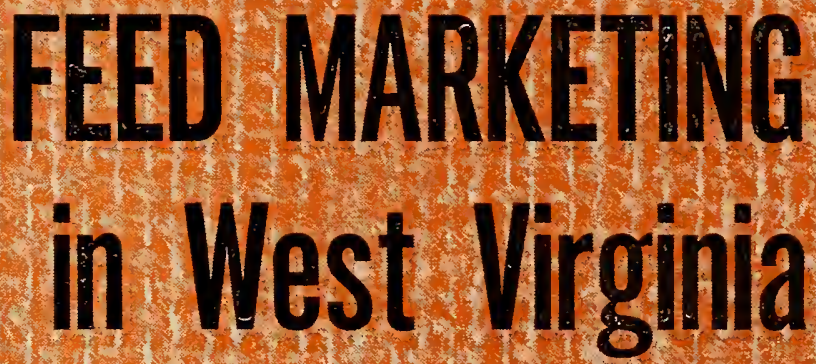

WEST VIRGINA UNIVERSITY AGRICULTURAL EXPERIMENT STATION 


\section{THE AUTHORS}

NORMAN NYBROTEN is Agricultural Economist at the West Virginia University Agricultural Experiment Station and Professor of Agricultural Economics in the College of Agriculture, Forestry, and Home Economics.

JAMES M. KESECKER was formerly Research Assistant in Agricultural Economics at the West Virginia University Agricultural Experiment Station and graduate student in Agricultural Economics.

\section{ACKNOWLEDGEMENTS}

This report is based on information collected in a study jointly organized by the Agricultural Experiment Station of West Virginia University and the Agricultural Marketing Service of the United States Department of Agriculture. Bennett S. White, Jr., Stanley W. Phillips, and Glenn L. Burrows served as consultants representing the Agricultural Marketing Service. This cooperation was made possible through funds provided through the Agricultural Marketing Act of 1946.

Excellent cooperation was received from the feed dealers in the State and from the farmers interviewed.

Notwithstanding the valuable organizational help received, the authors and the Agricultural Experiment Station are responsible for this report. Parts of the report have drawn freely upon information from Salient Characteristics of Feed Marketing in West Virginia, a thesis submitted to West Virginia University in 1954 by James M. Kesecker.

WEST VIRGINIA UNIVERSITY

Agricultural Experiment Station

College of Agriculture, Forestry, and Home Economics

H. R. VARney, Director

MORGANTOWN 


\section{CONTENTS}

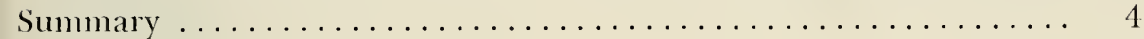

INTRODUCTION $\ldots \ldots \ldots \ldots \ldots \ldots \ldots \ldots \ldots \ldots \ldots \ldots \ldots \ldots \ldots \ldots \ldots \ldots \ldots$

TYPES OF FEED ESTABLISHMENTS $\ldots \ldots \ldots \ldots \ldots \ldots \ldots \ldots$

Location of Retail Feed Establishments ............ 6

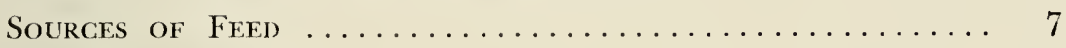

DEMAND FOR FEED $\ldots \ldots \ldots \ldots \ldots \ldots \ldots \ldots \ldots \ldots \ldots \ldots \ldots \ldots \ldots \ldots \ldots$

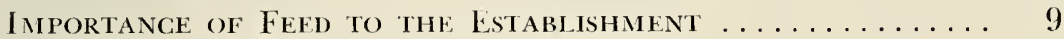

CAPITAL, IMPROVEMENTS AND TURNOVER ........ 10

GROSS RETAIL MARGINS FOR TON OF FEED ......... 12

ATTEMPTS AT POOLING FARMERS' ORDERS ......... 14

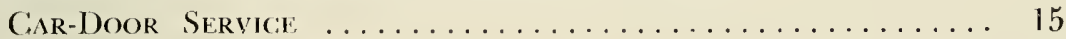

HAY - A CASUAL MARKET .................. 15

Bought in Winter $\ldots \ldots \ldots \ldots \ldots \ldots \ldots \ldots \ldots \ldots \ldots \ldots \ldots \ldots$

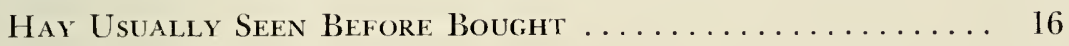

Sample Weighing Common ................ 18

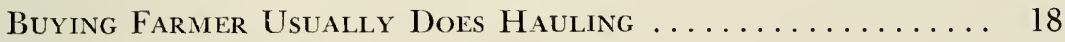

Prices Vary Widely $\ldots \ldots \ldots \ldots \ldots \ldots \ldots \ldots \ldots \ldots \ldots \ldots \ldots$

Hay Found Through Hearsay . . . . . . . . . . . . . . 19

Hay Carry-Over Usually LoOse Hay ............. 20 


\section{Summary}

N 1953 there were approximately 400 business establishments in West Virginia that retailed fifty or more tons of feed annually. These were well distributed throughout the State. Nearly all of these establishments handled lines other than feed, but in more than half of them feed was the most important line.

Ninety-six per cent of the mixed feed sold by feed retailers had been shipped in from outside the State. About three-fourths of the corn, grain, and hay handled by dealers cane from out-of-state sources.

Unless there is a rather revolutionary change in the type of agriculture, it appears that the demand for feed, or need for feed establishments, will not change much. Statements by farmers on what action they would take in case of feed shortages also indicated that great year-to-year fluctuations cannot be expected in the demand for feed. Half of the farmers indicated that they would buy hay if winter feed becomes scarce.

There is much variation among individual feed retailers in the yearly turn-over of capital tied up in feed. Very few retailers indicated that capital limited either the size or the nature of their business.

Retail margins on feed, although varying considerably among individual dealers, were quite uniform throughout the different sections of the State. Margins did not seem to be related to the credit policies of the dealers. Although there were notable exceptions, there seemed to be a relationship between average margins and the number of customers needed for $\$ 100$ worth of feed sales. The margins were higher where it took more customers. On the average it took twelve customers to buy $\$ 100$ of feed.

Although many of the dealers seemed enthusiastic about pooling orders and selling at the car door, this had met with very limited success. Ninety-seven dealers quoted car-door prices averaging $\$ 2.68$ per ton less than their regular store or warehouse prices.

Most of the hay purchased by farmers went directly from farm to farm rather than through retail establishments. Hay is handled in a casual manner; is subject to a wide price range; is not graded; and is often sold by the "stack." About one-third of the farmers interviewed stated that they aimed to carry hay over from one year to the next. 


\section{Some Features of FEED MARKETING In West Virginia}

\section{Introduction}

NORMAN NYBROTEN and JAMES M. KESECKER

EED marketing in West Virginia must respond to great variations

- both from the standpoint of time and place. The hills and mountains of the State contain relatively little crop land and serve as barriers to the equalization of the supply of and demand for feed. Farmers and feed dealers thus become more dependent upon local conditions than they would in less hilly country. Nearly sixty thousand farmers in the State buy feed for livestock or poultry. This is the most important cash farm expense in the State.

In an attempt to learn how feed is marketed in West Virginia, two surveys were made. In the first, 589 farmers were visited and questioned about their feed and livestock practices. These farmers were selected at random to represent farming in all of the State except the southern industry-coal area. (See Figure 1.) For this purpose, a farm was included in the sample if it had at least ten acres of cropped land in either of the two years immediately preceding the survey, or if the farm had at least eight animal units (livestock equal to eight cows from the standpoint of feed requirements), it was included regardless of crop acreage. This survey was conducted in the spring of 1953.

Later in 1953 all business establishments in the State known to handle at least fifty tons of feed annually were visited. From the 412 establishments visited, information was obtained regarding type of business, volumes, margins, and credit, along with other general data. Twenty-two of these were wholesale establishments. Although this report is based on results of both surveys, the main emphasis is on the survey of business establishments.

\section{Types Of Feed Establishments}

So much variation exists among feed handlers in the State that it is impossible to describe a typical one. This is true both from the standpoint of the nature of the business and the size of the business. Many lines of business are carried on in combination with feed. Information on what the four most important lines were, according to dollar 


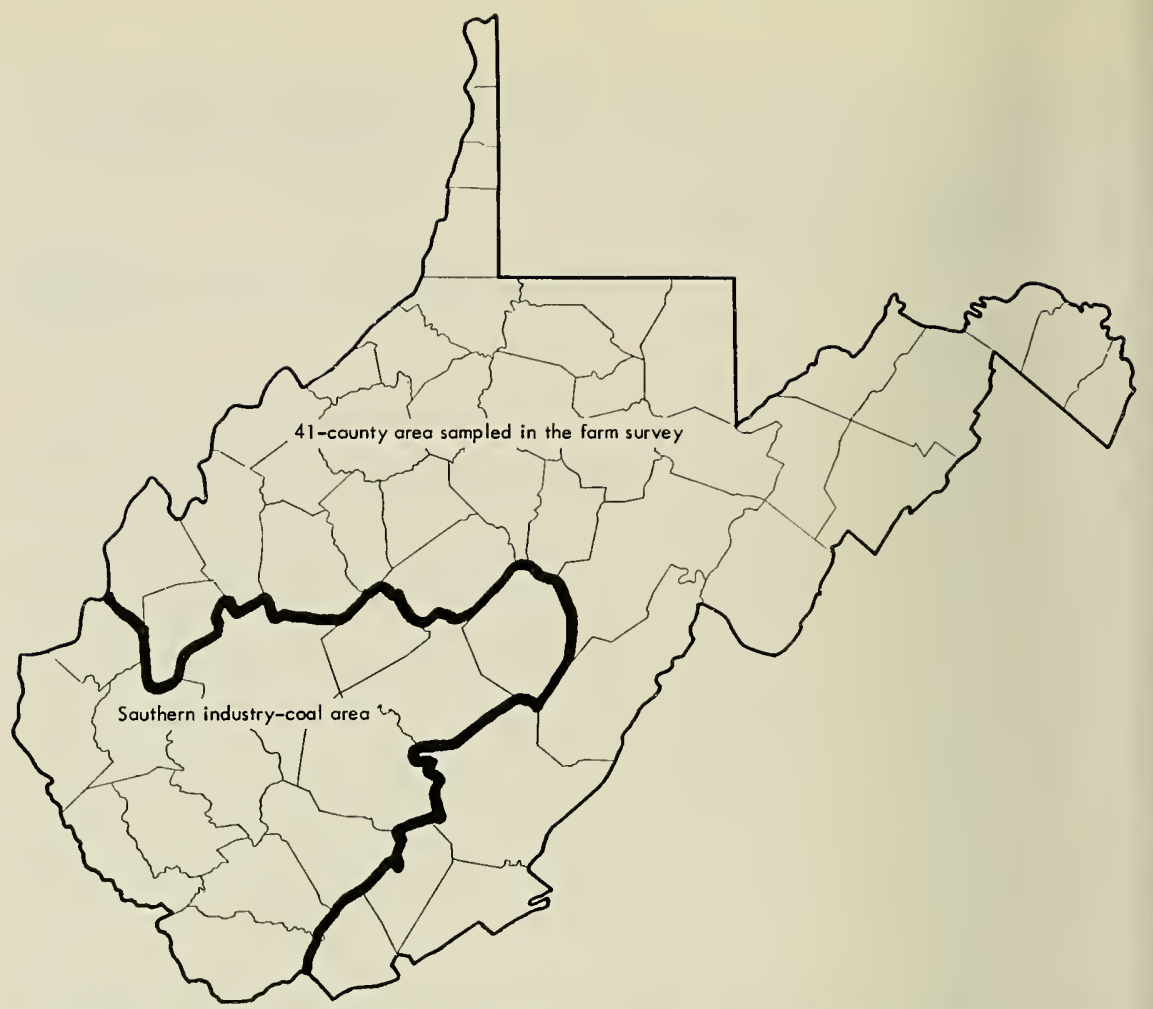

FIGURE 1. Map showing area represented in farm survey and the area omitted.

volume, was obtained from 372 establishments, only eleven of which did not rank feed of such importance. Some of the lines mentioned followed by the number of times mentioned are: feed, 361; fertilizer, 216 ; seed, 177; groceries, 137; general hardware, 122; dry goods, 61; home appliances, 25; and numerous others.

All of the retail establishments (390 stores) reported their most important line. Feed was most important in 251 stores, groceries in 91 , hardware in 13, dry goods in 7, general merchandise in 5, and in 23 stores it was some other line.

\section{LOCATION OF RETAIL FEED ESTABLISHMENTS}

West Virginia has a sufficient number of feed establishments. If there is an inefficiency resulting from the nature of the competition among the dealers, it is more likely the result of over-competition rather than under-competition. Feed stores are well distributed throughout the State. Figure 2 shows the number and average size of feerl stores in ten areas in the State. These are strictly retail establishments limited 


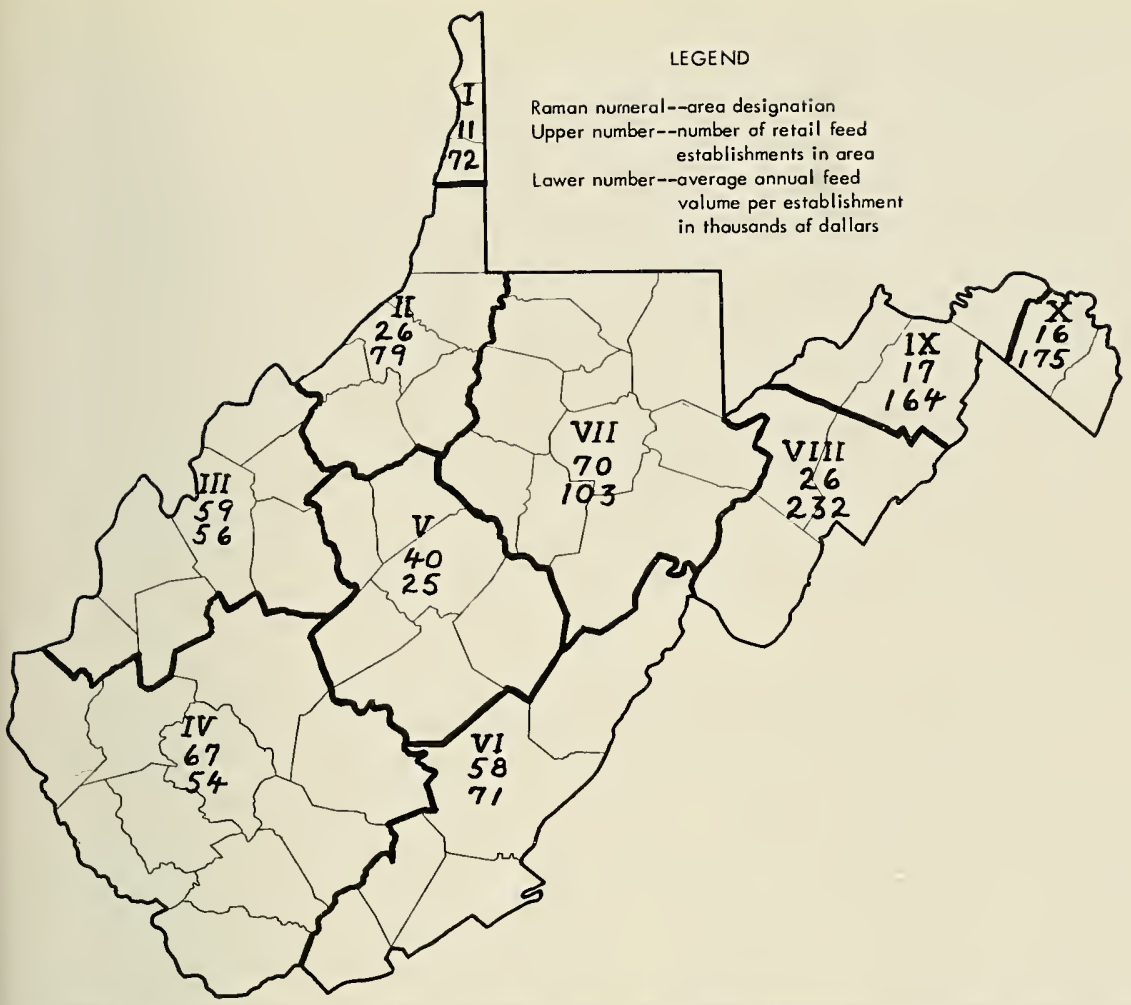

FIGURE 2. Number of retail feed stores and average feed volume per store in ten areas of West Virginia, 1953.

to stores handling at least fifty tons annually. Although there probably are many more stores handling less than fifty tons annually, they account for only a small percentage of the retail feed business.

The feed stores are usually located in low-rent areas. Railroads liave had a strong influence on the location of the buildings occupied by many. This is true even though many of the establishments no longer use railroad transportation in bringing in feed or feedstuffs. Approximately one-half of the establishments do not use the railroads at all, and many others use the railroads for only part of the in-shipments. Onetwelfth of the stores buy at least some feed in less-than-load lot (truck or rail). About 6 per cent get all their feed in less-than-load lots.

\section{SOURCES OF FEED}

Of the total tonnage of feed and feedstuffs handled annually by West Virginia retail and wholesale feed dealers (about 400,000 tons), about four-fifths comes from outside the State. The retail dealers re- 
ported about nine-tenths of their feed tonnage as having come from outof-state sources. ${ }^{1}$

The percentage of the feed or feedstuff that came from outside of the State depended upon the kind of feed. (See Table 1.) About threefourths of the grain, corn, and hay handled by retailers was reported to have come from outside the State. Ninety-six per cent of the mixed feed-which constitutes over three-fourths of the feed tonnage handled by retailers of feed-came from out-of-state sources. Most of the feed came from the north and west, notably from mills in Ohio.

Table 1. Sources of Feed Purchases as Reported by Feed Retailers (In-State, Out-of-State).

\begin{tabular}{|c|c|c|}
\hline TyPe OF FEed & $\begin{array}{c}\text { From Sodrces } \\
\text { WithIN THE State } \\
\text { per cent }\end{array}$ & $\begin{array}{c}\text { FrOM SOURCES } \\
\text { OUTSIDE THE STATE } \\
\text { per cent }\end{array}$ \\
\hline 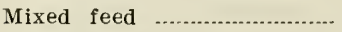 & 4 & 96 \\
\hline Grain* & 28 & 72 \\
\hline Corn* & 29 & 71 \\
\hline Hay & 25 & 75 \\
\hline
\end{tabular}

In the survey of farms, information was obtained on farmers' sales of grain, hay, and corn. Normally a farmer would sell either to a dealer or to another farmer. About one-third of the farmers selling corn sold to other farmers. The rest sold to dealers only. Usually wheat went from farmers to dealers. Only about one-sixth of the hay sold by farmers was sold to dealers. Some of the dealers handling hay were truckers rather than established feed dealers. As a result, very little hay moves from farms to feed dealers in West Virginia. Half of the corn sold by farmers was sold in the months of September and October, with a scatter of sales during the rest of the year. On the other hand, nearly all of the wheat was sold during the June-to-October period.

\section{DEMAND FOR FEED}

The principal sources of feedstuffs grown in West Virginia are hay, com, and pasturage. During the 10-year period of $1942-51$ a million tons of hay and about 11 million bushels of corn were grown per year in the State. Hay production has increased from an average of 773 thousand tons per year in the 1935-4I period to the present million-ton level. This was due almost entirely to increased acreage, with only it slight amount due to increased yields. The State's total corn production -because of continued reduction in acreage to about one-half of what it was twenty years ago-has decreased clespite steady increases in yields per acre.

1For statistics on tonnages of different kinds of feed sold annualiy in West Virginia, see West Virginia Agricultural Statistics, issued by U.S.D.A. anl West Virginia lepartmenl of Agriculture, State Capitoi, Charleston, $\mathrm{W}$. Va. 
Year-to-year variations in supply of the feedstuffs grown in West Virginia are relatively small. During the period 1942-51 the annual hay production has hovered near the million-ton mark, having always been within 10 per cent and usually within 5 per cent of a million tons. During this time an average of 151 thousand tons (about 15 per cent) has been carried over from the year before, so the availability of hay has been very much stabilized for the State as a whole. For individual farmers and localities of the State the percentage of the hay carried over has, of course, fluctuated much more than for the State as a whole.

Table 2 shows that half of the farmers would buy hay if they run short of winter feed. Since nearly all of the hay is sold from farmer to farmer, this local fluctuation in hay supply has only a slight effect on the established feed dealers' business. Even though a locality may be low on hay, it is probable that the farmers will get most of their hay from areas not requiring the channels of the established feed dealer.

Table 2. Action the 589 Sample Farmers Reported They Would Take in Response to Shortages of Winter Feed.

\begin{tabular}{|c|c|}
\hline $\begin{array}{c}\text { Action They Reported } \\
\text { THEy WOULD TAKE }\end{array}$ & $\begin{array}{c}\text { PER CENT OF } \\
\text { FARMERS SAMPLED }\end{array}$ \\
\hline Would buy hay & 50 \\
\hline No definite policy stated ......... & 27 \\
\hline Would sell livestock .................. & 15 \\
\hline Would buy mixed feed ............ & 3 \\
\hline Would "Farm out" stock ....... & 2 \\
\hline Other answers & 3 \\
\hline
\end{tabular}

Fifteen per cent of the farmers stated they would sell livestock if they run short of winter feed. This would tend to reduce the demand for mixed feeds usually handled by established dealers but probably not so much as might be imagined, for it is likely that most of the livestock sold would be of the type mainly kept on roughage.

It is evident that the amount of feed an individual feed dealer will sell depends much more on his competitive position locally than on changes in the total demand for feed. Only great changes in the feed marketing system or in the agriculture are likely to change this. In recent years the rapidly growing broiler industry has been a change of this latter type. The short-run demand for feed in the broiler-producing areas is more likely to depend on the price of the farm produce (broilers) than would be the case throughout the State.

\section{IMPORTANCE OF FEED TO THE ESTABLISHMENT}

In 336 retail feed establishments reliable information was obtained on dollar volumes of the feed business and for lines other than feed. 
The average feed volume per store was about 84 thousand dollars, varying from a few thousand dollars to more than a million dollars for the individual store.

The greater the feed volume was as a percentage of the total volume, the larger the feed volume was likely to be. The average total business was about 204 thousand clollars per store. (See Table 3.) In twenty of these stores feed sales represented not more than 5 per cent of the total sales. These stores were generally large, averaging 746 thousand dollars gross sales. The remaining 316 stores had an average gross dollar volume of 169 thousand dollars. In 149 stores more than half of the dollar volume was reported as having come from feed sales. In these the feed sales averaged 137 thousand dollars and total sales 173 thousand dollars.

Table 3. Average Annual Feed Volume and Per Cent of Total Volume Accounted for by Feed in 336 Retail Establishments.

\begin{tabular}{|c|c|c|c|}
\hline \multirow{2}{*}{$\begin{array}{l}\text { PER CENT OF TOTAL } \\
\text { BUSINESS ACCOUNTED } \\
\text { FOR BY FEED }\end{array}$} & \multirow{2}{*}{$\begin{array}{c}\text { No. OF } \\
\text { DEALERS }\end{array}$} & \multicolumn{2}{|c|}{ AVERAGE DOLLAR VOLUME } \\
\hline & & FEED & TOTAL \\
\hline $\begin{array}{l}\text { Group I } \\
0 \text { to } 25 .\end{array}$ & \multirow{2}{*}{119} & \multirow{2}{*}{$\$ 25,700$} & \multirow{2}{*}{$\$ 260,100$} \\
\hline Group II & & & \\
\hline 25.1 to 50 & \multirow[t]{2}{*}{68} & \multirow[t]{2}{*}{$71,90 n$} & \multirow{3}{*}{$\begin{array}{l}152,900 \\
197,600\end{array}$} \\
\hline Group III & & & \\
\hline 50.1 to 75 & 83 & 133,000 & \\
\hline $\begin{array}{l}\text { Group IV } \\
75.1 \text { to } 100\end{array}$ & & & \\
\hline $\begin{array}{l}75.1 \text { to } 100 \\
\text { Total }\end{array}$ & $\begin{array}{r}66 \\
366\end{array}$ & $\begin{array}{l}1+1,300 \\
\$ 84,270\end{array}$ & $\begin{array}{r}157,400 \\
\$ 203,659\end{array}$ \\
\hline
\end{tabular}

\section{Capital, Improvements, and Turnover}

Not being able to obtain capital for needed or desired improvements is evidently not a usual handicap to West Virginia feed dealers. There were only six dealers-less than 2 per cent of the total-who stated that they wanted to expand or make improvements but could not do so because the required capital was not available to them.

Forty-two dealers said that there were addled facilities that they should have for their feed business but did not plan to acquire them. Half of these dealers stated that they felt that the financial risk involved would be too great. About two-thirds of these feared general future business conditions, whereas one-third feared the future of local business conditions. Some of them feared both. The most common facility needed was more space of one kind or another, usually storage space. The most common equipment they stated they needed was equipment for handling bulk feed and mixing. 
The amount of operating capital feed dealers had tied up in feedfeed on hand plus credit outstanding for feed-varied throughout the year. In most parts of the State dealers had more capital tied up in winter and early spring. In the main broiler area-Grant, Hardy, and Pendleton counties-more of the dealers reported late summer or early fall as the time with most capital in feed and feed credit. This was also the case for the few dealers who bought large amounts of locallyproduced grain. The typical establishment retailing feed also carries several other "lines," so the operating capital for feed would not necessarily be idle in off-peak seasons.

Figure 3 shows the relationship between the greatest amount of operating capital seasonally "tied up" in feed and the gross annual feed volume. The "operating capital" for this purpose inclucles credit that has been extended to farmers and remained unpaid at the time of the year when the dealer's operating capital in feed was at a maximum.

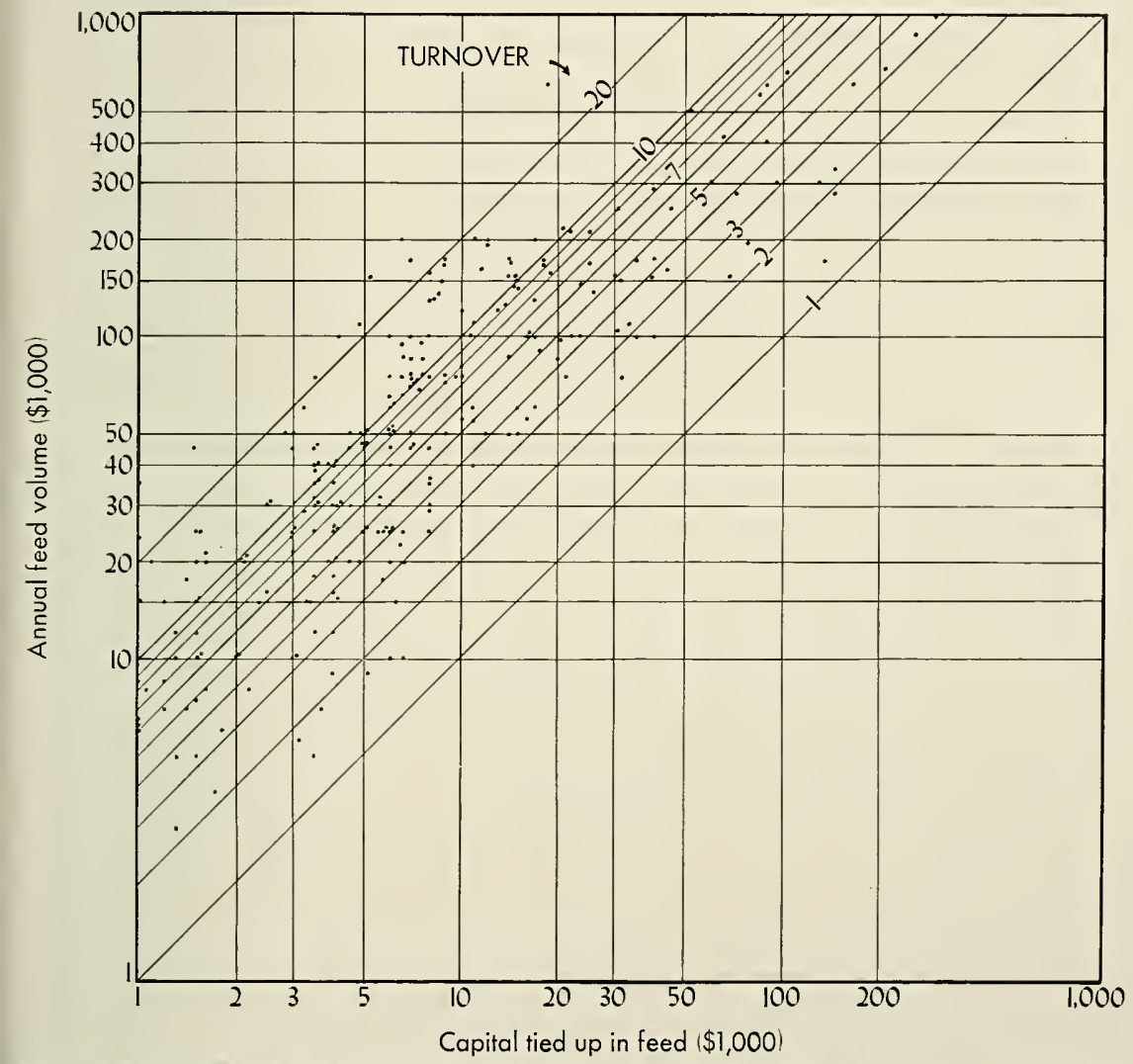

FIGURE 3. Annual feed volume, maximum capital seasonally tied up in feed, and the turnover for 267 establishments retailing feed in West Virginia. 
On the average there was a "turnover" of 9.4 times in feed; that is, the annual feed sales were 9.4 times the greatest amount of operating capital required for handling feed at any one time during the year. This varied extremely from one establishment to another. Eight dealers had turnovers of less than 2, whereas eight other dealers had turnovers of more than 20. Stores grossing less than $\$ 30,000$ on feed annually had an average turnover of 7.6 , compared with 10.2 for the stores grossing more than $\$ 30,000$. For stores grossing more than $\$ 30,000$ on feed there was no general relationship between feed volume and turnover. Put in terms of operating capital, it was found that establishments having less than $\$ 10,000$ operating capital in feed averaged a turnover of 10.0, compared with 7.2 for the establishments having more than $\$ 10,000$ of operating capital in feed. Turnover is in itself not a measure of success because establishments and the locale within which they operate differ so much. It was also found that a considerable number of feed dealers with adequate operating capital were in partial retirement and consequently not especially interested in soliciting or maintaining a large volume of business.

\section{Gross Retail Margins Per Ton of Feed}

There was much variation in margins per ton of feed among individual feed dealers. These varied from $\$ 2$ to $\$ 20$ per ton. No single factor was found that was highly associated with the amount of the margin. Generally-but with many notable exceptions-the dealers with smaller volumes were charging higher margins. Margins were not appreciably different in different parts of the State. (See Table 4.)

Records from 313 retail establishments were studied to learn whether there was a relationship between margins and credit policies. A total of 288 stores gave credit and averaged a margin of $\$ 8.88$ per ton,

Table: 4. Avrrage Gross Retall Margin Per Ton of Feen in West Virginia Divided into 10 Areas.

\begin{tabular}{|c|c|c|}
\hline $\begin{array}{c}\text { AREA IN THE STATE } \\
\text { 1JESIGNATED UN FIGURE : } \\
\text { UF THIS REPORT }\end{array}$ & $\begin{array}{c}\text { NuMBer of STORES } \\
\text { USED IN THE } \\
\text { AVERAGE }\end{array}$ & $\begin{array}{l}\text { AVERage Margin } \\
\text { PER TON OF FEEH) } \\
\text { (1)OLLARS) }\end{array}$ \\
\hline 1 & 8 & 7.ss \\
\hline 11 & 23 & 8.54 \\
\hline III & $5, \mathrm{i}$ & $5.3: 3$ \\
\hline IV & 19 & 8.61 \\
\hline $\mathrm{V} \quad \mathrm{n}-1-1-1-1-1-1$ & $\therefore 3$ & 8.20 \\
\hline vi $\ldots \ldots \ldots \ldots . . . . . .$. & 42 & 8.92 \\
\hline VII & 53 & 7.98 \\
\hline VIII & 18 & 9.19 \\
\hline IX & 16 & 8.88 \\
\hline $\mathrm{x} \quad$ - & 15 & 8.47 \\
\hline
\end{tabular}


compared with $\$ 8.04$ per ton for the stores operating on a cash basis. (See Table 5.) This difference was, however, caused by relatively few stores that gave credit and charged high margins. The typical store giving credit probably did not charge a higher margin than the strictly cash store. This was especially true for those stores giving credit but giving discounts for cash, of which there were fifty-six.

Table 5. Gross Margins Per Ton of Feed in 313 West Virginia Retail Feed Establishments Classed by Their Credit Policies.

\begin{tabular}{|c|c|c|c|c|c|}
\hline \multirow[b]{2}{*}{$\begin{array}{l}\text { MARgin PER TON OF } \\
\text { FEED IN DOLLARS }\end{array}$} & \multicolumn{3}{|c|}{$\begin{array}{l}\text { Establis HMENTs } \\
\text { GIVING CrEdit }\end{array}$} & \multirow{2}{*}{$\begin{array}{c}\text { Establishments } \\
\text { Not GIVING } \\
\text { CREdit }\end{array}$} & \multirow{2}{*}{$\begin{array}{l}\text { TOtal of AlL } \\
\text { Establis HMENTS } \\
\text { REGardLESS OF } \\
\text { CREDIT POLICIES }\end{array}$} \\
\hline & $\begin{array}{l}\text { DISCOUNT } \\
\text { FOR CASH }\end{array}$ & $\mid \begin{array}{c}\text { No } \\
\text { DISCOUNT } \\
\text { FOR CASH }\end{array}$ & TOTAL & & \\
\hline 15 and over ............ & 0 & 13 & 13 & 0 & 13 \\
\hline 10 to 14.99 & 9 & 77 & 86 & 11 & 97 \\
\hline 5 to 9.99 & 45 & 137 & 182 & 11 & 193 \\
\hline Under 5 & 2 & 5 & 7 & 3 & 10 \\
\hline Total & 56 & 232 & 288 & 25 & 313 \\
\hline Average ........... & $\$ 8.13$ & $\$ 9.01$ & $\$ 8.88$ & $\$ 8.04$ & $\$ 8.78$ \\
\hline
\end{tabular}

Feed retailers were asked what percentage of their gross volume they have had to write off as credit loss in recent years. This pertains to their total business rather than feed only. There were 279 who answered this. Forty-six stated that they had had no credit losses in recent years. For the group as a whole, the loss amounted to .86 per cent of the gross volume. Thirty-nine reported credit losses of 2 or more per cent of their gross.

The amount of margin taken on feed does not seem to be related to the percentage of credit loss. This can only mean that the dealers with higher losses either reduced their income or excelled in other phases of their management. Whatever the reason, it is evident that the farmer could not choose his feed retailer on the basis of credit policy only. Several dealers did make the comment, however, that they would need to consider credit risks more carefully, both from the standpoint of their own business and the welfare of their farmer customers.

Estimates on how many feed customers it would normally take to niake up $\$ 100$ of feed sales were available from 347 retail leed stores. On the average it took twelve feed customers to sell $\$ 100$ worth of feed, indicating that most of the sales must be small. (See Table 6.) Although exact information was not obtained, casual observations revealed a great number of one-bag sales. Also, some stores, although this does not total a great quantity of feed, serve a large number of customers with less-than-bag sales. 
Table 6. Gross Retail Margin on a Ton of Feed Classed by the Number of Customers Needed to Make $\$ 100$ of Feed Sales.

\begin{tabular}{|c|c|c|}
\hline $\begin{array}{l}\text { NUMBER OF CUSTOMERS } \\
\text { IT TAKES TO MAKE } \\
\$ 100 \text { OF FEED SALES* }\end{array}$ & $\begin{array}{l}\text { Number of } \\
\text { Stores } \\
\text { RhPortina }\end{array}$ & $\begin{array}{l}\text { Average Gross } \\
\text { Margin Per ToN } \\
\text { OF Feed }\end{array}$ \\
\hline Less than 5 & 29 & $\$ 9.10$ \\
\hline 5 to 9 & 82 & 8.29 \\
\hline 10 to $14 \ldots . . . .$. & 127 & 8.33 \\
\hline 15 to 19 & 77 & 8.87 \\
\hline 20 or more & 32 & 9.84 \\
\hline
\end{tabular}

* On the average it took 12 customers to buy $\$ 100$ worth of feed.

Table 6 shows that the margin per ton is peculiarly related to the number of feed customers needed for $\$ 100$ of feed sales. There is a tendency, and logically so because of the increased costs, for stores which make smaller sales per customer to charge a higher margin per toll. There were, however, twenty-nine stores which needed less than five customers to make $\$ 100$ in sales, which went contrary to the trend by having a higher-than-average margin. A high margin does not necessarily mean that a high price was charged by the retailer-he may have made a higher margin by buying for less.

\section{Attempts at Pooling Farmers' Orders}

Thirty-one of the feed establishments visited reported that they had made or were making attempts at combining enough advance orders from farmers to make up a carload lot-in one instance a truck load. Seven of the thirty-one dealers stated that they had tried but had been unable to get enough orders together. Among the various reasons given for the failure was the opinion that farmers thought the dealer had ordered too much feed and expected prices to fall.

The dealers believed they were effecting appreciable savings to farmers through the pooled orders. These dealers were asked how much less this feed cost the farmers than if they bought at regular prices from the storeroom or warehouse supply. Answers to this ranged from $\$ 2$ to $\$ 8$ per ton for seventeen dealers that had quoted both prices. The average of the seventeen was $\$ 4.80$ per ton. It is probable that the difference was not quite this much because some of the dcalers may have quoted car-door prices on pooled orders and at-farm prices for the regular supply, but there should not have been enough of this to affect the difference greatly.

One dealer pools orders for oats, one for corn, and onc for beet pulp, but most of the pooling was for mixed feed. This was true even though some of the clealers stated that the most successful pools had been on feeds or fecdstuffs sharply seasonal in either demand or supply, 
especially in meeting local emergencies. Many of the feed establishments in the State are either cooperatives or agencies of cooperatives, but this does not seem to have brought about pooling through the dealer establishment. The methods of operation in cooperatives, insofar as pooling is concerned, were found to be much the same as in private establishments. Although data are not available to relate the extent to a desired degree of accuracy, it is known-especially from freight reports of railroads-that a considerable amount of pooling in feeds and fertilizers takes place. These pools are operated by farmers rather than by established dealers.

Of twenty-two establishments reporting financial arrangements on pooled orders, only two definitely had advance payment for the feed ordered. One additional establishment pooled broiler feed on a contract basis. In all the establishments the feed dealer assumed the responsibility of collecting for the feed. This, in some instances, led to farmers not calling for the feed when the car came in. Four of the dealers stated that this was an important problem in their pooling. Several of the dealers pointed out that it is less difficult to pool the orders of the larger farmers than those of the smaller farmers.

\section{CAR-DOOR SERVICE}

Pooled orders from several larmers do not necessarily have to go directly from the railroad car to the farmer, but there is a tendency to associate car-door service with pooling. About half of the dealers in the State are not in a position to quote car-door prices. A total of 188 dealers gave estimates on how much costs would be lowered through car-door service compared with handling the feed in the store or warehouse. The estimates varied greatly and averaged $\$ 2.64$ per ton. Actually, ninety-seven dealers (about one-fourth) were quoting car-door prices averaging $\$ 2.68$ per ton less than their regular store or warehouse prices. The regular prices usually included some services not included at the car door. A farmer can probably effect a real saving in his feed bill if he is willing to take the feed when it comes in, help load it, and haul it.

\section{Hay-a Casual Market}

About 8 per cent of the farmers stated that they usually buy hay. During the feeding season ending in the spring of 1953 and the season ending in the spring of 1952 more of the famers bought hay. About 20.5 per cent of the farmers had bought hay in one of those seasons. Indications are that between 55 and 65 thousand tons of hay were bought by the farmers in the forty-one counties studied during each of these 
two seasons. About 68 per cent of the hay was bought from other farmers." The Census shows that the farmers in these counties sold 44,046 tons in the year of 1949 .

\section{BOUGHT IN WINTER}

Figure 4 shows the time of year when hay was bought during the two seasons mentioned above. Most of the hay was bought in January, February, and March, with very little in summer.

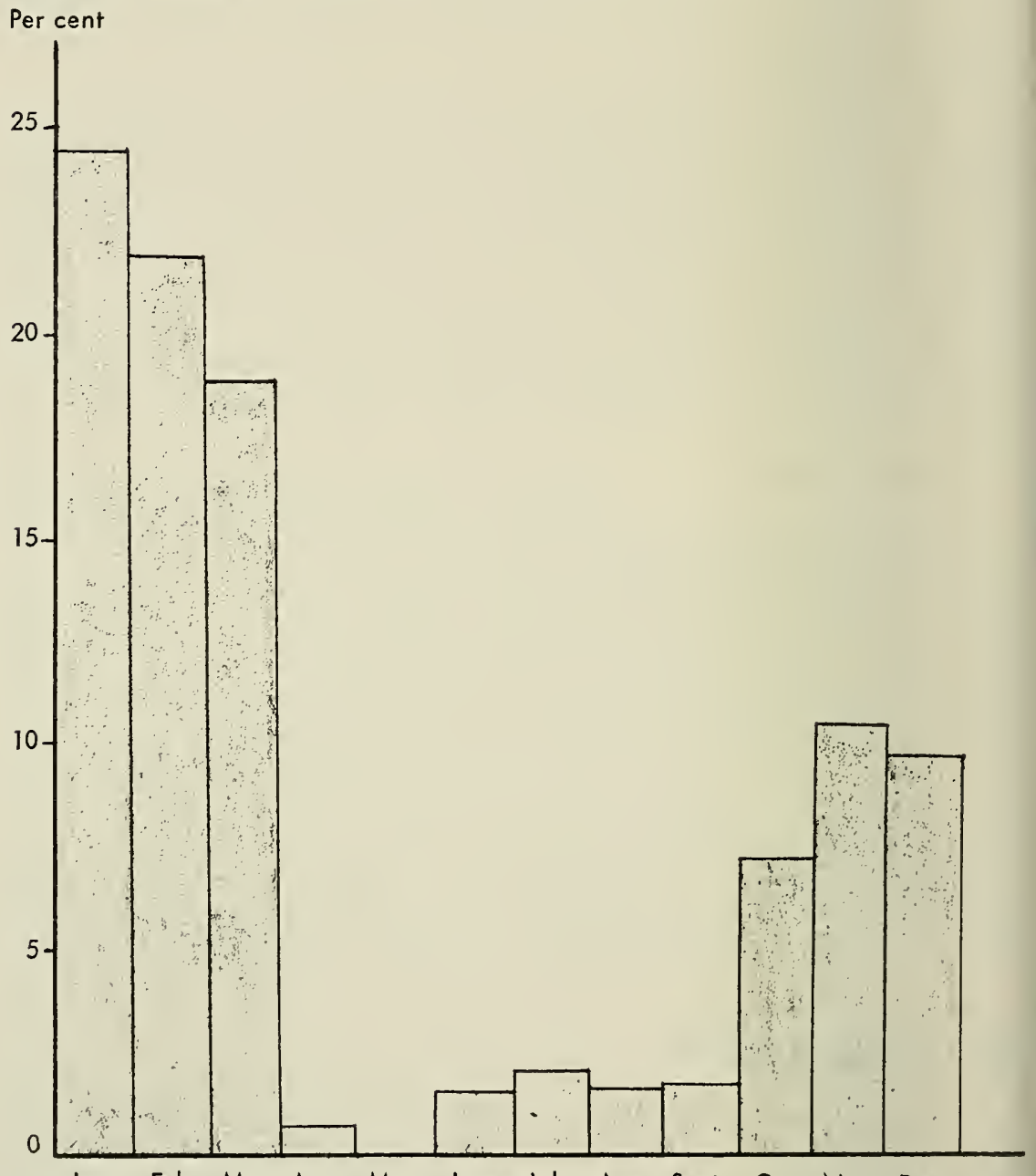

Jan. Feb. Mar. Apr. May June July Aug. Sept. Oct. Nov. Dec. FIGURE 4. Monthly percentages of total hay bought in a two-year period ending April, 1953, by farmers representing forty-one West Virginia counties.

2 These were farmers having cropped at least 10 acres of land in 1952 or, if not, usually wintered at least 8 animal units of livestock. 
Very few farmers bought hay at haying time. The exception to this was usually the case in which a farmer would put up a neighbor's hay on shares. Many farmers stated that they had put up hay on shares. In these cases the typical share to the owner of the land was one-half. A few owners made the stipulation that the hay had to be fed in the field on which it had been made. Most of the hay put up on shares was timothy.

Several farmers obtained hay in a rather unique manner. A farmer makes hay on a neighbor's land and pays for it by cutting "filth." This means that he cuts unwanted vegetation, such as weeds or brush. Usually the land on which this is done belongs to a rural resident who lives on land he formerly farmed but for some reason the farming has been abandoned. Usually there is no specific agreement. The hay-making farmer usually gets all the hay.

\section{HAY USUALLY SEEN BEFORE BOUGHT}

Very little of the hay purchased had been graded. Most of the farmers indicated that they did not know that hay could be bought on a grade basis. In about two-thirds of the different hay purchases the buying farmer saw the hay prior to purchase. Of the lots bought from established feed dealers, one-third had been seen by the farmer before he bought. More than 90 per cent of the hay lots bought from other farmers had been seen, whereas only 5 per cent of the lots bought from truckers had been seen. This probably does not mean that the farmer had this much confidence in the trucker's hay, but rather that the farmer felt more free to reject the hay upon arrival.

The farmers surveyed were asked to rate the quality of hay they had either sold or bought in the two years immediately prior to the survey. As a whole, they felt they were getting better hay from established dealers or truckers than they were from other farmers. (See Table 7.) These farmers rated about seven-eights of the hay they had received from dealers or truckers as either "good" or "excellent," compared with only a little more than one-third of the hay received directly

Table 7. West Virginia Farmers' rating of the Quality of hay BOUgHT OR SOLd IN A 2-YEAR PERIOD ENDING APRIL, 1953.

\begin{tabular}{|c|c|c|c|c|}
\hline \multirow{2}{*}{$\begin{array}{c}\text { QUALITY } \\
\text { ESTIMATED } \\
\text { BY FARMER } \\
\text { INTERVIEWED }\end{array}$} & \multicolumn{2}{|c|}{ HAY BOUGHT } & \multicolumn{2}{|c|}{ HAY SOLD } \\
\hline & $\begin{array}{c}\text { From } \\
\text { OTHER } \\
\text { FARMER }\end{array}$ & $\begin{array}{c}\text { FROM } \\
\text { DEALER OR } \\
\text { TRUCKER }\end{array}$ & $\begin{array}{c}\text { TO } \\
\text { OTHER } \\
\text { FARMER }\end{array}$ & $\begin{array}{c}\text { TO } \\
\text { DEALER OR } \\
\text { TRUCKER }\end{array}$ \\
\hline $\begin{array}{l}\text { Excellent } \\
\text { Good } \\
\text { Fair } \\
\text { Poor }\end{array}$ & $\begin{array}{c}\text { per cent } \\
3.6 \\
33.4 \\
59.0 \\
4.0\end{array}$ & $\begin{array}{c}\text { per cent } \\
11.7 \\
74.5 \\
12.7 \\
1.1\end{array}$ & $\begin{array}{c}\text { per cent } \\
13.8 \\
55.0 \\
27.7 \\
3.5\end{array}$ & $\begin{array}{c}\text { per cent } \\
32.1 \\
6.2 \\
61.7 \\
.0\end{array}$ \\
\hline
\end{tabular}


from other farmers being rated that highly. It is more difficult to compare their ratings on hay sold to other farms with that sold to dealers and truckers because the dealers and truckers had taken more "excellent" but other farmers had taken much more "good" hay. Ratings by both the buying farmer and the selling farmer of the same hay were too few to make a valid comparison. The ratings were intended, however, to apply to the hay moving between farmers in the State. It is apparent that farmers selling hay rated it higher than did farmers buying it. It appears that a program in which the feed value of hay would be determined, and backed up with specifications, could eliminate the need for buyer inspection. This would save either a great deal of traveling or hauling expense as well as avoid distasteful argument.

\section{SAMPLE WEIGHING COMMON}

Of the 861.25 tons of hay that the sample farmers had bought and moved directly from other farmers, only about one-tenth had actually been completely weighed. The most common way that weight estimates were made was to weigh a few bales as a sample and from this estimate the weight of the load. This method was used to estimate the weight of more than 60 per cent of the hay that moved directly from farmer to farmer. Nore than one-fourth of the hay that moved directly from farmer to farmer was not weighed in any manner. Nore than half of this hay was sold by the "stack." This is onc of the factors making necessary pre-purchase inspection by the buying farmer.

\section{BUYING FARMER USUALLY DOES HAULING}

The hay that moved directly from farm to farm was hauled an average of 201/2 miles, compared with 8 miles for the hay bought from established dealers. About 84 per cent of the farm-to-farm hay lots were hauled by the buying farmer, 5 per cent by the selling farmer, and 11 per cent by a third party. The average amount of hay per purchase in the lots hauled by a third party was 4.2 tons, compared with 4.7 tons if hauled by either of the farmers. All of a purchase was not, of course, necessarily taken in a single load.

\section{PRICES VARY WIDELY}

The prices for hay varied considerably from onc transaction to another during the 2-year period studied. Although much of the variation was due to local differences in the supply-dentand conditions, much of it was also due to differences in hay quality as well as conditions attached to individual transactions, such as how far and by whom the hay was hauled. Farmers, when asked how they learn the market price of hay, most commonly stated that they either asked neighbors or dealers or 


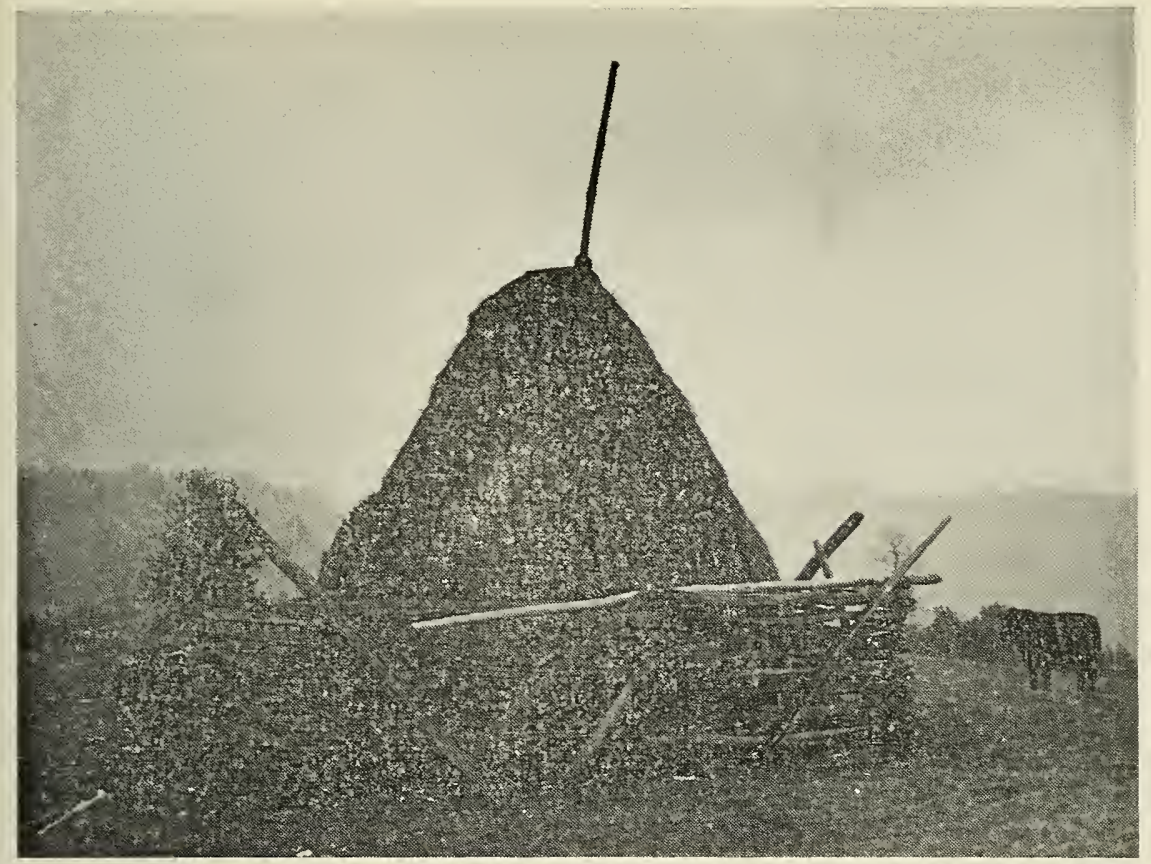

A TYPICAL West Virginia haystack. It is built to a peak around a pole. Usually several of these are located throughout the hay field to reduce hay hauling. It is the most common way of storing hay, even from season to season.

learned what other farmers were paying. It was also rather common for farmers to say that they had to have hay and give the impression that price was definitely a secondary consideration. Evidently no public service or agency was effective in getting information to farmers which would help them determine the market price of hay.

\section{HAY FOUND THROUGH HEARSAY}

Finding hay that can be bought when local supplies are short is a familiar but compelling problem to the livestock farmer. The farmers who had bought hay were asked, "How did you find the hay?" By far the most common answer was that they found it through a neighbor rather than through any established marketing channel or service. In the majority of these cases the initiative was taken by the farmer seeking hay. Learning of hay supplies through neighbors occurred about twice as often as learning of hay supplies through dealers and truckers. A significant number of farmers drive into hay areas in adjoining states and "ask around" until they find a farmer who has hay to sell. It was not learned to what extent this practice led to arrangements which became of a more permanent nature. Frequently hay was acquired from relatives, even though they lived many miles away. 


\section{HAY CARRY-OVER USUALLY LOOSE HAY}

Of the 589 farmers interviewed, about one-third stated that they usually planned to carry some hay over from one year to the next. Evidently it is not easy for the farmers to plan the feeding so they will "come out right" on their hay supplies. There were 146 farmers, about 25 per cent, who carried over more than they had planned to in one of the two years ending either in the summer of 1951 or 1952. Actually, fifty-four of these had not intended to carry any over but found themselves long on hay.

More than 90 per cent of the hay carried over was loose hay. Only 25 farmers of the 271 carried hay over in baled form. In no instance was hay carried over in chopped form, and in only one case was hay carried over in a silo. Most of the farmers, 59 per cent, carried loose hay over in stacks. Loose hay in the barn was carried over by 32 per cent of the farmers, and 9 per cent carried over baled hay. The baled hay was usually in a barn or shed. Estimates of the Crop Reporting Board and the Bureau of Agricultural Economics in West Virginia Agricultural Statistics show an average of 151 thousand tons of hay on hand in the State on May 1, ranging from 123 thousand to 236 thousand tons. 

